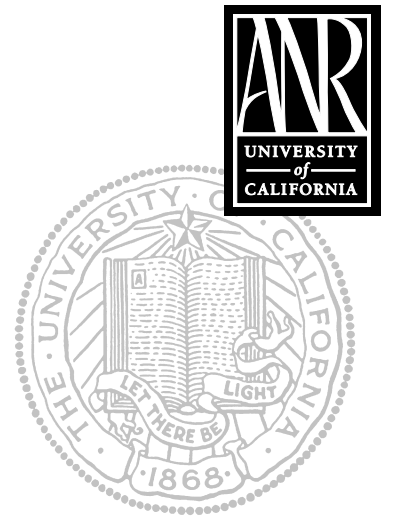

UNIVERSITY OF CALIFORNIA

Division of Agriculture and Natural Resources

http://anrcatalog.ucdavis.edu

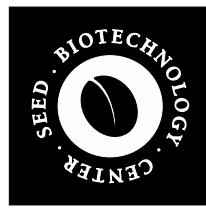

Produced by

Seed Biotechnology Center, UC Davis http://sbc.ucdavis.edu

\title{
Identity Preservation of Agricultural Commodities
}

F. J. SUNDSTROM, Executive Director, University of California Foundation Seed Program and California Crop Improvement Association; JACK WILLIAMS, University of California Cooperative Extension County Director and Farm Advisor, Sutter and Yuba Counties; ALLEN VAN DEYNZE, Biotechnology Specialist, Seed Biotechnology Center, University of California, Davis; KENT J. BRADFORD, Professor of Vegetable Crops and Director, Seed Biotechnology Center, University of California, Davis

Identity preservation (IP) refers to a system of production, handling, and marketing practices that maintains the integrity and purity of agricultural commodities. In its simplest form, IP has been employed since the beginning of agriculture when the seeds and grain of different crops were first traded separately. As the seed and food industries developed, the purity and quality expectations of buyers and processors increased and standards were established. Seed certification programs such as that used by the Association of Official Seed Certifying Agencies (AOSCA) play a major role in maintaining seed purity standards at levels established by the industry for national and international trade. Similarly, commodity traders, marketing organizations, and food processors have established purity and quality tolerances for specific end-product uses. As crops and production systems have diversified to meet market demands, the need for segregation and identity preservation of agricultural commodities has increased.

Crop varieties with unique product quality traits, such as high oleic sunflowers, low linolenic canola, or high oil corn, require IP programs to channel these commodities to specific markets to capture the added value. Similarly, organic commodities must be produced according to specific criteria and segregated in the marketplace in order to receive premium prices. The introduction of crops developed using biotechnology also requires new IP programs, as markets differ in their acceptance of these commodities. While some countries, such as the United States, Canada, Argentina, and China, have readily adopted crops enhanced through biotechnology, this has not been the case everywhere, particularly in the European Union (EU) and Japan. In addition, some countries are instituting labeling laws that require the segregation and identification of seed and food products developed using biotechnology. Thus, additional criteria for IP are based upon the method by which a variety was developed and whether it contains traits introduced via biotechnology (Suslow, Thomas, and Bradford 2002). Together, these factors are increasing the demand for IP programs that can certify the identity and composition of agricultural commodities. In many cases, changes in production and marketing procedures are required to meet these more stringent standards.

This publication describes the essential features of IP programs, using seed certification as a model. Issues related to crops developed using biotechnology are addressed, and examples of specific commodity IP programs, including the California Rice Certification Act and the National Organic Act, are presented. Finally, economic issues associated with IP programs are discussed. 


\section{COMPONENTS OF IP SYSTEMS}

Identity preservation systems do not begin with testing of the end product. Rather, IP is a system of standards, records, and auditing that must be in place throughout the entire crop production, harvesting, handling, and marketing process (fig. 1). Seed certification is an example of a successful IP program. Seed certification was introduced in the 1920s and 1930s as a mechanism to maintain the genetic purity of publicly

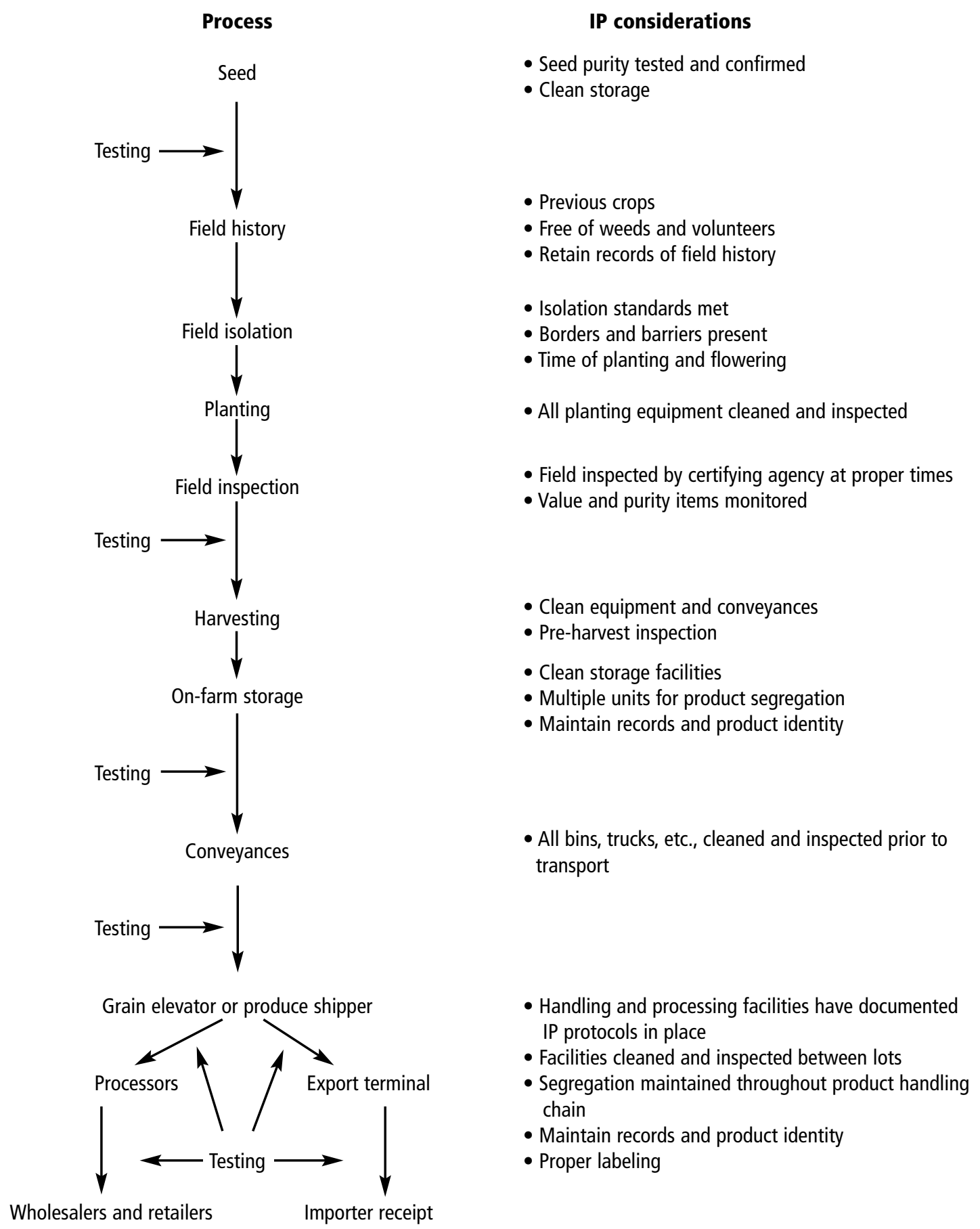

Figure 1. The IP process and factors to consider at each step, including testing and auditing points. 
released crop varieties. Agricultural experiment stations bred and released improved varieties, but as seeds were saved by farmers and sold to their neighbors, the desirable attributes of the varieties were often lost through random genetic changes and contamination with other crop and weed seeds. Seed certification programs established a pedigree system in which breeder's seed was planted to produce foundation seed, foundation seed was planted to produce registered seed, and registered seed was planted to produce certified seed, which was sold to the farmer for crop production. Purity standards were established for each category, being most stringent for foundation seed and somewhat lower for registered and certified as the volumes of seed produced increased. Inspections of seed production fields by a certifying agency (e.g., an AOSCA member) ensured that the varieties remained true to type and that if off-types, weeds, or diseases were present, they were below established tolerances. Seeds meeting the quality standards were labeled with special tags indicating their certification category. Seed certification programs have been highly successful in maintaining the integrity of crop varieties and in providing farmers with seeds of known pedigree with high purity and quality. As IP programs are developed for agricultural commodities other than planting seed, they often follow principles similar to those used in seed certification. Thus, in describing the components of IP programs, seed certification is often used as the model.

\section{Planting Seed and Tolerances}

The purity of any commercial agricultural product propagated by seed begins with the purity of the seed planted. It is evident that the purity of the seed stock must equal or exceed the purity standards of the final product. However, it is virtually impossible to assure that all handling and conveyance equipment and storage facilities are completely free of contamination, so even foundation seed is seldom 100 percent pure. Currently, AOSCA purity standards for certified seed average 98 percent across species (AOSCA 2000, California Crop Improvement Association 2002). Consequently, IP systems with product purity standards greater than 98 percent must begin with extraordinarily pure seed stocks. Different product tolerances are established in specialized IP programs based on market-driven standards. It is not uncommon for a single commodity to have multiple quality tolerance thresholds based on diverse market needs.

\section{Field History and Eligibility}

Fields eligible for IP certification must not have grown a crop the previous year that could produce inseparable contaminating weeds or volunteer plants. In some cases, multiple-year rotations may be necessary between crops to achieve low contamination levels. Records and field maps must be maintained for up to 5 years to allow documentation of previous crop history.

\section{Field Isolation}

Crops must be isolated either spatially or temporally from potentially contaminating pollen sources. The degree of isolation depends on flower characteristics, sexual compatibility with neighboring crops, pollen quantity and viability, and mode of pollen dissemination. Self-pollinating crops such as rice or wheat require relatively small isolation distances that are primarily intended to prevent mechanical mixtures during harvesting. Cross-pollinating crops require as much as 2 miles $(3.2 \mathrm{~km})$ or more of isolation from plants of the same species to prevent outcrossing, depending upon the flower structure and mode of pollen transfer. Insect- and wind-pollinated crops require various isolation distances depending upon the type of insect and the distance that pollen can be carried. Seed certification standards serve as a guide to minimum isolation distances (table 1). These guidelines have been found in practice to be sufficient to meet seed certification standards, but pollen flow can be 
Table 1. Minimum recommended isolation distances (feet) for foundation, registered, and certified generations of seed crops

Key words for consideration

\begin{tabular}{|c|c|c|c|c|}
\hline Crop & Foundation & Registered & Certified & (see AOSCA standards) \\
\hline \multicolumn{5}{|l|}{ Self-pollinated crops } \\
\hline \multicolumn{5}{|l|}{ Bean } \\
\hline field and garden ${ }^{1}$ & 0 & 0 & 0 & \\
\hline lima & 30 & 30 & 30 & $100 \mathrm{ft}$ for Fordhook \\
\hline cowpea $^{1}$ & 0 & 0 & 0 & \\
\hline Bermudagrass & 900 & - & 165 & $10 \%$ rule $^{2}$ \\
\hline \multicolumn{5}{|l|}{ Cotton } \\
\hline same type $e^{1,2}$ & 1,320 & 1,320 & 20 & 20 buffer rows \\
\hline different type ${ }^{2}$ & 2,640 & 2,640 & 660 & 20 buffer rows \\
\hline Pea (field) ${ }^{1}$ & 0 & 0 & 0 & \\
\hline Peanut ${ }^{1}$ & 0 & 0 & 0 & \\
\hline Pepper ${ }^{3}$ & 200 & 100 & 30 & \\
\hline Rice $^{2,4}$ & 10 & 10 & 10 & planting direction \\
\hline \multicolumn{5}{|l|}{ Small grain } \\
\hline barley, oat, triticale, and wheat ${ }^{1}$ & 0 & 0 & 0 & hybrid barley \\
\hline buckwheat and rye & 660 & 660 & 660 & diploid and tetraploid rye \\
\hline Soybean ${ }^{1}$ & 0 & 0 & 0 & \\
\hline \multicolumn{5}{|l|}{ Tobacco } \\
\hline open-pollinated & 150 & 150 & 150 & varieties of same type \\
\hline hybrid & - & - & 150 & male sterile and fertile lines \\
\hline \multicolumn{5}{|l|}{ Tomato ${ }^{3}$} \\
\hline open-pollinated & 200 & 100 & 30 & \\
\hline hybrid & - & - & 0 & \\
\hline \multicolumn{5}{|l|}{ Wind-pollinated crops } \\
\hline \multicolumn{5}{|l|}{ Corn } \\
\hline inbred lines ${ }^{5}$ & 660 & - & - & $\begin{array}{l}\text { varieties of same color and texture; } \\
\text { dent corn }\end{array}$ \\
\hline \multicolumn{5}{|l|}{ foundation $^{5}$} \\
\hline single cross & 660 & - & - & $\begin{array}{l}\text { varieties of same color and texture; } \\
\text { dent corn }\end{array}$ \\
\hline backcross & 660 & - & - & $\begin{array}{l}\text { varieties of same color and texture; } \\
\text { dent corn }\end{array}$ \\
\hline hybrid & - & - & 660 & $\begin{array}{l}\text { varieties of same color and texture; } \\
\text { dent corn }\end{array}$ \\
\hline open-pollinated & - & - & 660 & $\begin{array}{l}\text { varieties of same color and texture; } \\
\text { dent corn }\end{array}$ \\
\hline sweet & - & - & 660 & field size \\
\hline \multicolumn{5}{|l|}{ Grasses } \\
\hline cross-pollinated ${ }^{6}$ & 900 & 300 & 165 & diploids and tetraploids; field size \\
\hline apomictic/self-fertile & 60 & 30 & 15 & diploids and tetraploids; field size \\
\hline \multicolumn{5}{|l|}{ Millet } \\
\hline cross-pollinated ${ }^{7}$ & 1,320 & 1,320 & 660 & \\
\hline self-pollinated ${ }^{1}$ & 0 & 0 & 0 & \\
\hline sorghum ${ }^{2}$ & 990 & 990 & 660 & pollinator parent; dissimilar types \\
\hline hybrid seedstock & 990 & - & - & \\
\hline hybrid & - & - & 660 & $\begin{array}{l}\text { bloom time; pollinator parent; } \\
\text { contaminating source }\end{array}$ \\
\hline
\end{tabular}


Table 1. Minimum recommended isolation distances, cont.

\begin{tabular}{|c|c|c|c|c|}
\hline Crop & Foundation & Registered & Certified & $\begin{array}{l}\text { Key words for } \\
\text { consideration } \\
\text { (see AOSCA standards) }\end{array}$ \\
\hline \multicolumn{5}{|l|}{ Insect-pollinated crops } \\
\hline Alfalfa ${ }^{2,8}$ & 900 & - & 165 & $10 \%$ rule $^{2}$ \\
\hline hybrid $^{8,9}$ & 1,320 & - & 165 & varietal adaptation region \\
\hline \multicolumn{5}{|l|}{ Canola } \\
\hline self-pollinated ${ }^{10}$ & 660 & - & 330 & \\
\hline cross-pollinated & 1,320 & - & 330 & \\
\hline Clover (red and white) ${ }^{2}$ & 900 & - & 165 & $\begin{array}{l}\text { diploids and tetraploids; } \\
\text { field size }\end{array}$ \\
\hline Okra & 1,320 & 1,320 & 825 & \\
\hline Onion & 5,280 & 2,640 & 1,320 & \\
\hline Safflower & 1,320 & 1,320 & 1,320 & \\
\hline \multicolumn{5}{|l|}{ Sunflower ${ }^{2,11}$} \\
\hline open-pollinated & 7,920 & & 7,920 & $\begin{array}{l}\text { oil and non-oil types; } \\
\text { volunteers and wilds }\end{array}$ \\
\hline hybrid & - & - & 6,600 & $\begin{array}{l}\text { oil and non-oil types; } \\
\text { volunteers and wilds }\end{array}$ \\
\hline restorer or maintainer lines & 6,600 & - & - & \\
\hline male sterile & 13,200 & - & - & \\
\hline Watermelon 2,12 & 10,560 & 5,280 & 2,640 & citron $^{2}$ \\
\hline
\end{tabular}

Note: $-=$ Not applicable.

${ }^{1}$ Adequate distance to prevent mechanical mixture is necessary.

${ }^{2}$ See California Crop Improvement Association 2002.

${ }^{3}$ Distance may be reduced by half if different generations of the same variety are adjacent.

${ }^{4}$ Distance between fields of the same variety is $10 \mathrm{ft}$ if ground drilled, $50 \mathrm{ft}$ if ground broadcast, and $100 \mathrm{ft}$ if aerial seeded.

${ }^{5} \mathrm{No}$ isolation required for production of hand-pollinated seed.

${ }^{6}$ Isolation between classes of the same variety may be reduced to $25 \%$ of distance otherwise required.

Isolation between millets of different genera is $6 \mathrm{ft}$.

${ }^{8}$ Distances between different generations of the same variety may be reduced to $10 \mathrm{ft}$.

${ }^{9}$ Parent lines in a crossing block or seed and pollen lines in a hybrid production field must be separated by $6 \mathrm{ft}$ or more.

${ }^{10}$ Required isolation between generations of the same variety is $10 \mathrm{ft}$.

"This does not apply to Helianthus similes, $\mathrm{H}$. ludens, or $\mathrm{H}$. agrestis.

${ }^{12}$ Minimum distance may be reduced by $50 \%$ if a field is adequately protected by natural or artificial barriers.

affected by the environment and insect pollinator activity. These recommended isolation distances may need to be increased depending upon the effect of contamination. For example, hybrid seed production fields or fields producing high-value quality traits often require greater isolation to achieve purity standards. Similarly, greater isolation is required to reduce the likelihood that pollen from outside the field will introduce undesired traits into the crop, such as biotech traits into an organic field. Isolation can also be achieved by planting crops at different times so that their flowering periods do not overlap. Border rows of the IP crop are often left unharvested to intercept stray pollen and prevent contamination of the remainder of the field. Related weeds and volunteer crop plants or home gardens can also be sources of pollen contamination. Certifying agencies inspect fields and the surrounding areas to ensure that isolation standards are met. 


\section{Equipment and Facilities}

All equipment used in production, including seeding, field maintenance, and harvest, must be cleaned and inspected before and after each use. All dryers, millers, storage facilities, and processing equipment must be cleaned and inspected between each product lot to assure that segregation is maintained and no physical contamination occurs. Certification standards for facilities that handle IP products have been established and published (AOSCA 2000).

\section{Sampling and Testing}

In many cases, samples of a product must be tested at various stages to confirm product identification, purity, and quality. Identity preservation programs must use statistically representative sampling and testing techniques to ensure reliable results. Test results are dependent upon the sampling procedure, and a single sample at a single audit point is inadequate to evaluate an IP system. Statistical procedures must be applied to accurately determine the number of samples and the numbers of seeds or grains required to generate a test result with an acceptable confidence level (Remund et al. 2001). Seed stock sampling, production field sampling, and postharvest sampling each requires different considerations. The USDA's Grain Inspection, Packers and Stockyards Administration (GIPSA) provides guidelines on selecting a sampling protocol and on collecting bulk samples (see "For Additional Information," below). The guiding principle is that the sample must be representative of the total quantity of material to be tested or test results are compromised. Significant differences in test results between labs may occur solely due to sampling differences. Analytical error in the testing laboratory can also result in test differences, but in many cases, sampling methods, rather than test sensitivity and accuracy, limit the ability to properly detect the presence or absence of specific crop traits. Tests to detect the presence of transgenes introduced through biotechnology are described further in the section below, "Crops Developed Using Biotechnology."

In addition to using an appropriate sampling procedure, sampling must also be performed at meaningful audit points within the chain of product custody (fig. 1). Common sampling and testing points are at

- the seed source for planting

- the field prior to harvest

- on-farm storage or local elevator receipt

- first processor receipt

- final processor receipt

- export terminal receipt

- overseas importer receipt

\section{Record Maintenance and Labeling}

The party responsible for contracting IP services must maintain records of all field designations, harvest amounts, storage bin locations, and product transfers. IP products must be identified, segregated, and labeled at all times in the market chain. Labeling standards depend on the product and market in which it is sold. Official auditing and labeling are available from various service providers to designate products meeting IP certification standards. 


\section{IP CERTIFICATION AND CHANNELING PROGRAMS}

Identity preservation certification programs can work in two ways to ensure the purity and value of specific crop traits. A true IP program is not simply product segregation, but rather a process that results in certification that a product meets specific quality standards. Using pure planting stocks, maintaining proper field isolations to reduce adventitious presence of contaminants, using clean equipment and facilities, maintaining records, sampling and verifying product identity, and traceability all play critical roles in establishing confidence in the integrity of the system and the quality of the products. Alternatively, channeling is a process-based certification program focused on the segregation of large volumes of commodities. With this strategy,

- farmers and handlers develop plans to produce certain crops

- plans are approved by a third-party certifying agency

- the certifying agency audits the production and handling of the commodity

- audit reports are filed and any corrective action is taken

- certificates are issued and presented at product delivery

The emphasis in channeling is on the integrity of the process used to produce the commodity, but the final product may or may not be tested specifically for the quality traits of interest. True IP programs may cost as much as 5 to 10 times more to implement and maintain than channeling systems due to more stringent standards and the additional costs of repeated sampling and testing.

The channeling of agricultural products for specific markets has been used as long as markets have been diversified. Different varieties, grades, and types of products have long been directed to different, specific end uses, and there are many successful examples of such market diversification and product segregation, including long, medium, and short grain rice, white and yellow corn, and fiber quality grades in cotton. However, the introduction of crops developed using biotechnology and subsequent concerns over their safety have increased the demands upon commodity IP systems, and failure to properly preserve the identity of a product can be devastating. For example, StarLink was a hybrid corn variety produced through biotechnology that provided protection from the European corn borer. It was approved by the U.S. Environmental Protection Agency for animal feed but not for human consumption, pending further tests for potential allergenicity. The particular Bacillus thuringiensis (Bt) protein produced in StarLink (Cry9C) was not immediately broken down in simulated digestion tests, and because some allergens are also not readily digested, more data were required before it could be approved for human consumption. A strict IP program was to be implemented to ensure that the StarLink grain was only destined for animal feeds, but this program failed in practice. Even though only 0.5 percent of the total U.S. corn acreage was planted with StarLink corn in crop years 1999 and 2000, some of this corn was mixed with corn sold for human uses and traces of its DNA (but not the Cry9C protein itself) were found in taco shells and related corn products sold in supermarkets in the United States and abroad. While no danger to human health was anticipated from this low level of exposure, and no adverse effects in humans was ever documented, the USDA and Aventis Crop Science (the developer of StarLink corn) moved quickly to remove contaminated products from the marketplace. Food manufacturers, milling companies, retailers, and seed dealers recalled or withheld from the market all products that were identified as containing StarLink DNA, and StarLink registration has been voluntarily withdrawn. The estimated cost of this IP failure may exceed $\$ 1$ billion. This incident exposed weaknesses in the grain commodity IP system that must be addressed if biotech or value-added crops are to be grown and marketed with confidence. 
Some features of IP programs specific to crops developed using biotechnology are discussed below, along with two new IP programs that go into effect in 2002, the California Rice Certification Act and the National Organic Program. These examples illustrate how the principles presented above are incorporated into real IP and channeling programs.

\section{CROPS DEVELOPED USING BIOTECHNOLOGY}

Although the term biotechnology can be defined in various ways, it is used here to indicate the use of recombinant DNA techniques to introduce genes into plants (Suslow, Thomas, and Bradford 2002). The expression of those genes in plants results in specific production or quality traits. The first large-scale introduction of a transgenic crop occurred in 1996 with the release of herbicide-tolerant soybeans. Along with insect resistance conferred by the Bacillus thuringiensis (Bt) protein, this first generation of biotech crops exhibited improved agronomic traits (also called input traits). Due to these agronomic advantages, U.S. growers enthusiastically embraced this technology, and by crop year 2001, the USDA estimated that 68 percent of soybeans, 26 percent of corn, and 69 percent of cotton in the United States were planted with varieties enhanced by biotechnology. Worldwide, 130 million acres (52.6 million ha) of transgenic crops were grown in 2001.

The second generation of transgenic crops to enter the market incorporates value-enhanced qualities for end users, also called output traits. An exciting example is GoldenRice, a rice variety that accumulates beta-carotene (the precursor to vitamin A) and iron in the grain, potentially reducing childhood blindness and anemia in countries where rice is a staple food. Many additional products under development will increase crop value for specific end-product uses and will therefore require segregation from traditional commodities in order to command a market premium.

In the United States, once a transgenic variety has been evaluated by the U.S. Department of Agriculture, the Food and Drug Administration, and/or the Environmental Protection Agency and released for sale, there are no additional IP requirements beyond those normally in place for that commodity. That is, a soybean, cotton, or corn variety may contain herbicide or insect resistance, but regulatory agencies have determined that these varieties are substantially equivalent with respect to their food or fiber value to similar varieties without the biotech traits. However, this lack of distinction is not the case in many other countries to which U.S. agricultural products are exported, and even in the United States some processors and retailers are reluctant to include transgenic crops in their products due to the possibility of consumer rejection. Thus, it has become important to be able to identify and segregate crops developed using biotechnology and to test for the presence of introduced genes in commodities.

There are several methods used to test for the absence or presence of transgenes in seed and grain products, each with its specific advantages and disadvantages (see Anklam et al. 2002, and table 2). Seed bioassays for herbicide tolerance are easy to use and relatively inexpensive but require significant time and resources. Lateral flow strips and enzyme-linked immunosorbent assays (ELISAs) use immunological techniques based on antibodies to detect specific proteins (e.g., Bacillus thuringiensis protein) associated with the trait of interest. Flow strips are simple and rapid, generally giving results in less than 10 minutes, while ELISA assays require specialized equipment and take longer to perform. The sensitivity of these methods depends on the protein being assayed and the technique employed. For example, some lateral flow strip assays for the Cry9C protein found in Starlink corn can detect 1 positive seed in 800 total seeds, while ELISA tests can detect as little as 1/10,000 (table 2). 
Table 2. Analytical tests to detect traits introduced into plants through biotechnology

\begin{tabular}{|c|c|c|c|c|c|}
\hline Test type & Target & $\begin{array}{c}\text { Cost (\$) } \\
\text { per sample }\end{array}$ & Speed & Sensitivity & Current traits* \\
\hline Bioassay & $\begin{array}{l}\text { herbicide } \\
\text { tolerance }\end{array}$ & 40 & 7-14 days & quantitative & RR, LL, BXN, STS, IMI \\
\hline Strip tests & Protein & $5-10$ & $10 \mathrm{~min}$ & $\begin{array}{l}\text { qualitative; } \\
1 / 200 \text { to } 1 / 1,000\end{array}$ & RR, LL, Bt Corn \\
\hline ELISA & Protein & $15-40$ & $4 \mathrm{~h}$ & $\begin{array}{l}\text { quantitative; } \\
1 / 800 \text { to } 1 / 10,000\end{array}$ & RR, (CP4) Bt corn \\
\hline PCR & DNA & $150-200$ & 1 day & $\begin{array}{l}\text { qualitative; } \\
1 / 10,000\end{array}$ & All commercial events \\
\hline $\begin{array}{l}\text { Quantitative } \\
\text { PCR }\end{array}$ & DNA & $250-325$ & 1 day & $\begin{array}{l}\text { quantitative; } \\
1 / 10,000\end{array}$ & All commercial events \\
\hline
\end{tabular}

*RR: Roundup-ready; LL: Liberty Link; STS: Sulfonylurea-tolerant soybeans; IMI: Imidazolinone-tolerant; BXN: Buctril-tolerant.

Lateral flow strips can have a relatively short shelf life and their reliability can be significantly influenced by the level of protein in the sample. In addition, as a product is processed, the potential for protein degradation and removal increases and testing for the protein becomes less reliable.

DNA-based tests assay for the DNA sequences that encode the transgenic trait rather than for the protein(s) produced in the plant. Various techniques can be used to detect specific DNA sequences, but most commonly the DNA of interest is amplified using polymerase chain reaction (PCR). This procedure uses enzymes that can synthesize DNA in combination with short pieces of DNA that uniquely match those in the gene of interest. If the target DNA is present in the sample, the PCR process makes millions of copies of the targeted DNA region, which can then be detected either qualitatively or quantitatively, depending upon the procedure. PCR assays are extremely sensitive, capable of detecting just a few molecules of the target DNA; however, this sensitivity also makes PCRs subject to false positive results if stringent sample preparation and cleanliness procedures are not followed. As DNA is more stable than protein in processed products, DNA-based tests rather than protein-based tests are often employed after processing. Still, no allergenicity or other adverse effects have ever been found from DNA, which is present in all foods, so while the detection of unexpected transgenic DNA in a sample may represent a breakdown in an IP program, as in the StarLink case, it does not imply a safety hazard as long as the corresponding protein is not present.

Currently, even though some countries require testing and labeling of transgenic commodities, there are no accepted national or international test standards for detection of specific crop genetic traits. GIPSA is in the process of establishing a U.S. laboratory accreditation system for this purpose, but trait reporting methods can vary among laboratories. For example, in tests to verify the absence of biotech traits, some labs report the percentage of positive seeds or grains in the total pool of seeds or grains tested, while others report total detected DNA as a weight percentage of total DNA. Sellers and buyers should agree on testing laboratories and testing methods before sales transactions are finalized in order to avoid possible confusion and disagreement. The types of tests currently employed by U.S. labs are listed in table 2 along with some of their strengths and limitations (Shoemaker et al. 2001, Anklam et al. 2002, USDA GIPSA 2002). 
A special case of biotech crops requiring additional stringency in IP procedures is when plants are engineered to produce pharmaceuticals. These plant-made pharmaceuticals (PMPs) provide an alternative method of producing antibodies and other therapeutic proteins at a lower cost than current methods that use cultured mammalian cells (Thomas, Van Deynze, and Bradford 2002). Guidelines have been developed by the USDA Animal and Plant Health Inspection Service (APHIS) for the stringent isolation of fields with these crops to prevent pollen and seed movement (USDA APHIS 2002). In addition to the spatial and temporal isolation methods described above, in some cases additional controls, such as the bagging of flowers, emasculation, and male sterility, may also be required to prevent dissemination of transgenic pollen.

\section{CALIFORNIA RICE CERTIFICATION ACT OF 2000}

California produces a wide array of rice types for domestic and world markets. Highquality medium grain rice is currently grown on about 90 percent of the acres, but specialty types are increasingly important. These include sweet, basmati, aromatic, scented, arborio, and colored rice, plus premium short and medium grain rice destined primarily for the Pacific Rim and a small amount of long grain rice for table and soup use. Currently, at least sixteen public and several private varieties are commercially produced. In addition, small batches of unique rice are brought into California from other states and countries for processing and sale. Collectively, these represent a wide range of traits to meet the needs of numerous market niches.

California's complex market situation requires procedures to ensure that different types of rice are not mixed. In addition, transgenic varieties with unique production and quality traits are on the horizon although none is currently grown commercially in California. While biotechnology has enormous potential to create rice with a wide variety of nutritional, medicinal, and industrial uses, it is important to prevent mixtures with other, similar-looking rice that is not transgenic. Processors are demanding assurances of purity in response to the consumer reaction to transgenic crops, particularly in export markets. Hence, the California rice industry sponsored the California Rice Certification Act of 2000 to ensure the ongoing high quality of California rice, maintain consumer confidence, and enhance and protect California's reputation as a provider of high quality rice.

The Rice Certification Act of 2000 (California Food and Agriculture Code 2000) was signed into law on September 22, 2000, and its provisions will go into effect for the 2003 crop year. This legislation contains both mandatory and voluntary IP components allowing for the certification of any verifiable attribute of rice. The California Rice Commission (CRC) recognized that

"There is a growing need to maintain the identity of various types of rice to satisfy increasing consumer demand for specialty rice varieties. This demand requires providing the industry with the ability to establish the terms and conditions for the production and handling of rice in order to minimize the potential for the commingling of various types of rice, and in order to prevent commingling where reconditioning is infeasible or impossible."

All rice varieties for commercial production in California possessing "traits of commercial significance" will be required by statute to be produced within an IP certification system. The cost of the mandatory program will be borne by the growers of the specialty rice seeds and grains. The CRC is empowered to collect fees, receive and investigate complaints, provide notice of action regarding alleged violations, and seek injunctive relief and other legal means to prevent violation of the act. The Rice Certification Act is an example of a product-based IP system. 
All characteristics resulting from mixing that may adversely affect the marketability of rice are defined as having "commercial impact." Included are those that can be visually identified (e.g., bran color, grain shape, grain size) and that require specialized equipment or procedures (e.g., lab cooking tests, taste panels, DNA or specific protein tests) to determine their identity or composition. For example, if rice with red bran were mixed with Calrose type medium grain, the mixture would have lower value and hence be commercially impacted. All rice grown, sold, or processed in California will be evaluated for characteristics of commercial impact, including rice brought into California for processing or sale, and IP protocols can be required for production, handling, transportation, and storage of a given variety to prevent contamination of other rice. Several specialty types of rice currently grown and successfully segregated in California (e.g., sweet, scented, basmati, arborio, and colored bran rice) may eventually be identified as having characteristics of commercial impact. IP procedures for these varieties are already in place. However, traits that are not visible, such as herbicide tolerance, especially if the varieties are grown widely, will require extra vigilance to keep them separate from other similar varieties.

An advisory committee will recommend regulations to the Secretary of the California Department of Food and Agriculture pertaining to rice identified as having characteristics of commercial impact. The advisory committee will consider each variety separately and render a judgment (on the basis of science, economics, and market experience) as to whether a given attribute has the potential for commercial impact. If it does, the committee will then establish terms and conditions of production, transportation, drying, and storage to segregate the commodity from other rice types. These terms may include establishing a method of seed application to prevent contamination of neighboring fields, buffer zones between fields, handling requirements to prevent mixtures, and other IP requirements.

An expressed intent of the Rice Certification Act is to encourage research and development of new types of rice. However, to prevent contamination and introduction of exotic pests, the committee must approve research protocols to ensure that the research will not have negative commercial impact. Researchers will be required to submit their protocols, the location of the research, and acreage to the advisory committee and to follow required procedures. Specific attributes of the rice for research do not have to be revealed. Research activity is limited to 50 or fewer acres ( $\leq 20$ ha) of a single type of rice. The advisory committee also reviews procedures for rice brought into the state from other states or countries for research purposes. Current state and federal regulations for bringing such rice into California will apply unless the committee can justify that they are not acceptable. The act does not apply to rice research conducted by the University of California except when such rice enters the channels of trade.

Separate from the work of the advisory committee, the act allows the CRC to establish a voluntary program to certify any verifiable attribute of rice. Certified rice may be labeled with the words: "This lot of rice certified (specified attribute) in accordance with the California Rice Certification Act of 2000."

Certifiable attributes include any of those characteristics that can be verified, such as origin, scent, herbicide tolerance, colored bran, mochi quality, variety, and so on. One may certify, with the appropriate documentation and procedures, that a given lot of rice has or does not have a particular attribute. Hence, rice could be certified as nontransgenic or free of colored bran. Rice with and without commercial impact in the form of seed, rough, or milled rice can all be certified. The act does not certify rice as organic although specific attributes of organic rice could be certified. 


\section{THE NATIONAL ORGANIC PROGRAM}

The USDA National Organic Program (NOP) implemented a certification program for the production of organic crops effective October 21, 2002 (USDA NOP 2002). The program aims to

- establish national standards governing the marketing of certain agricultural products as organically produced products

- assure consumers that organically produced products meet a consistent standard

- facilitate interstate commerce in fresh and processed food that is organically produced

The NOP has all the features of an IP program, namely, accreditation and certification, production and handling standards, a national list of allowed and prohibited substances, testing, labeling, record keeping, and enforcement. Accredited state programs will administer and enforce organic certification using the NOP standards as a minimum.

Operations or portions of operations that produce or handle agricultural products that are intended to be sold, labeled, or represented as organic must be certified by accredited agents. Farms with less than \$5,000 annual sales are exempt from the certification process, but must abide by the NOP standards to sell their product as organic. The NOP is a process-driven (i.e., channeling) program based on audited methods and practices of production and handling rather than on measurable properties of the product itself. Organic growers must submit a plan to be approved by their certification provider. The plan describes how production practices meet the standards of the NOP. The certifying agency then monitors for compliance with the approved plan.

Organic products must be grown on land or media that have had no prohibited substances applied for the prior 3 years. The production area must have distinct buffer zones, boundaries, and diversions to prevent unintended contamination with prohibited substances, including pesticides, transgenic crops, and sewage. Crops must be planted with organically grown seed, unless similar varieties are not available, except for production of sprouts or perennial crops where the product will not be sold as organic for 1 year. The crop and products must be harvested and handled at all points before sale to the consumer such that commingling and physical contact with nonorganic products and substances is prevented. Records must be maintained and kept for 5 years after production of the product. Organic products must exhibit the USDA Organic Seal and meet the label requirements of the NOP for one of the following categories:

- "100 percent organic"

- "organic" (minimum 95 percent organic)

- "made with organic ingredients" (minimum 70 percent organic)

The United States does not regulate the import or export of organic products. The largest export markets for U.S. organic foods are in Europe, Japan, and Canada. The EU will administer a program similar to the NOP effective January 1, 2004. Currently, the EU only allows imports of organic products from countries, such as the United States, whose national standards are recognized as equivalent to EU standards. Similarly, Japan has proposed standards and third-party certification requirements that are virtually identical to the NOP Rule. The establishment of consistent national and international standards for organic production, identity preservation, and labeling will give producers and marketers clear guidelines and assure consumers that the organic products they buy have been produced in accordance with those standards. 


\section{THE ECONOMICS OF IDENTITY PRESERVATION}

In general, there is a direct correlation between increased product purity standards (tolerance levels) and higher IP costs. Standards for the final product largely determine the complexity of production, handling, processing, testing, and labeling procedures required to maintain the identity of a commodity, and therefore the costs associated with the IP program. The benefits of value-added output traits can only be captured if purity of the product is maintained throughout production and marketing, but the added value must be sufficient to pay for the added IP costs. Many believe that the introduction of value-enhanced crops will further decommodify the U.S. commodity handling system (Riley and Hoffman 1999). There will be a move away from bulk commodity handling practices to a system that tracks and preserves the genetic or process identity of products from seed to end user. In such systems, specialized biotech crops and organic crops may result in greater farm profitability due to higher commodity prices. However, economists disagree on whether these traits or attributes will possess sufficient value to be shared with all participants in the value chain (Kalaitzandonakes 1999, Shoemaker et al. 2001). Identity preservation is only successful if it enables all handlers in the value chain to share the increased value achieved by segregation. If a disproportionate burden of IP costs falls on any one group in the handling chain, IP systems will fail economically.

The burden of maintaining purity and the cost of IP is distributed differently under different conditions (Shoemaker et al. 2001). In the case of higher-value commodities, such as corn with higher oil or improved nutritional content, a price premium must offset the increased costs of IP. In other cases, IP is employed primarily to ensure the absence of a particular component in a commodity, such as in the marketing of nonbiotech foods. In this case, the burden falls primarily on the producer and marketer of the nonbiotech product to ensure the purity of the product, along with the substantial additional costs for testing to confirm this (table 2). While some markets pay a premium for nonbiotech certification, in many cases there is little or no price premium for such products since their inherent value is no greater than similar commodities not subjected to IP and testing. As organic products must also be biotech-free, organic producers face potential additional costs of testing to assure the absence of biotech traits. The need to test for biotech traits depends entirely upon the regulatory, marketing, and labeling requirements of different countries and product categories, which are largely under development and in a state of flux. In particular, the levels at which threshold tolerances are set for adventitious contamination have a large impact on IP requirements and costs. Thus, it is difficult to determine precise cost-benefit-risk relationships at the present time. No doubt these issues will be settled in the marketplace as the higher potential value for both producers and consumers is balanced against the costs of delivering identity preserved commodities. One thing is clear: the economic success of IP systems depends upon having sufficient market premiums at all points in the value chain.

\section{CONCLUSIONS}

Identity preservation is a system that segregates and maintains the integrity and purity of agricultural commodities in order to enhance the value of the final product. Some system components, such as process documentation, record keeping, auditing, and testing, are common to all IP programs. Other aspects are specific to the biological and market characteristics of each crop, product, or process. IP programs can be designed to address either the presence or the absence of particular traits or components. As market needs continue to evolve and availability of enhanced-value traits increases (by both biotech and traditional breeding methods), niche-marketing opportunities will 
grow. Systems must be in place to assure that useful, attainable, and mutually agreeable (between buyer and seller) product tolerance thresholds and standards are established, and that all steps in the marketing chain can benefit from the added value. IP certification of agricultural commodities can provide the greater choice and value desired by both agricultural producers and consumers.

\section{REFEREN CES}

Anklam, E., F. Gadani, P. Heinze, H. Pijnenburg, and G. Van Den Eede. 2002. Analytical methods for detection and determination of genetically modified organisms in agricultural crops and plant-derived food products. Eur. Food Res. Technol. 214: 3-26.

Association of Official Seed Certifying Agencies (AOSCA). 2000. Genetic and crop standards. Meridian, ID. http://www.aosca.org

California Crop Improvement Association. 2002. Foundation seed and certification services. http://ccia.ucdavis.edu/

California Food and Agriculture Code. 2000. California Rice Certification Act of 2000. 2000. Section 20, chapter 4: 55000-55255.

http://www.leginfo.ca.gov/cgi-bin/calawquery? codesection=fac

Kalaitzandonakes, N. 1999. A farm level perspective on agrobiotechnology: How much value and for whom? AgBioForum 2(2): 61-64. http://www.agbioforum.org

Remund, K. M., M. A. Dixon, D. L. Wright, and L. R. Holden. 2001. Statistical considerations in seed purity testing for transgenic traits. Seed Science Research 11: 101-119.

Riley, P., and L. Hoffman. 1999. Value-enhanced crops: Biotechnology's next stage. ERS/USDA Agricultural Outlook. 3: 18-23. http://www.ers.usda.gov/publications/AgOutlook/mar1999/ao259e.pdf

Shoemaker, R., J. Harwood, K. Day-Rubenstein, T. Dunahay, P. Heisey, L. Hoffman, C. Klotz-Ingram, W. Lin, L. Mitchell, W. McBride, and J. Fernandez-Cornejo. 2001. Economic issues in agricultural biotechnology. ERS/USDA Information Bulletin No. 762. http://www.ers.usda.gov/publications/aib762/

Suslow, T. V., B. R. Thomas, and K. J. Bradford. 2002. Biotechnology provides new tools for planting. Oakland: University of California Division of Agriculture and Natural Resources, Publication 8043. http://anrcatalog.ucdavis.edu

Thomas, B. R., A. Van Deynze, and K. J. Bradford. 2002. The production of therapeutic proteins in plants. Oakland: University of California Division of Agriculture and Natural Resources, Publication 8078. http://anrcatalog.ucdavis.edu

USDA APHIS (Animal and Plant Health Inspection Service). 2002. Summary of the confinement measures for organisms being field tested in 2002. http://www.aphis.usda.gov/ppq/biotech/pdf/pharm-2002.pdf

USDA GIPSA (Grain Inspection, Packers and Stockyards Administration), Tech. Ser. Division. 2000. Sampling for the detection of biotech grains. http://www.usda.gov/gipsa/biotech/sample2.htm

— 2002. Test kit performance verification. http://www.usda.gov/gipsa/tech-servsup/metheqp/testkit.htm

USDA National Organic Program. The NOP Final Rule. 2002. http://www.ams.usda.gov/nop/ 


\title{
FOR ADDITIONAL INFORMATION
}

Agricultural Biotechnology in California Series. http://sbc.ucdavis.edu/ Seed Biotechnology Center Resource Series. http://sbc.ucdavis.edu/ UCBiotech, University of California, Berkeley. http://www.ucbiotech.org/ USDA Grain Inspection, Packers and Stockyards Administration (GIPSA). http://www.usda.gov/gipsa/ University of California Division of Agriculture and Natural Resources. Online catalog. http://www.anrcatalog.ucdavis.edu

For information about ordering other ANR Communication Services publications and videos, please contact

\author{
University of California \\ Agriculture and Natural Resources \\ Communication Services \\ 6701 San Pablo Avenue, 2nd Floor \\ Oakland, CA 94608-1239 \\ Telephone: (800) 994-8849 or (510) 642-2431 \\ FAX: (510) 643-5470 \\ E-mail inquiries: danrcs@ucdavis.edu
}

Visit the ANR Communication Services website at http://www.anrcatalog.ucdavis.edu

\section{Publication 8077}

(C)2002 by the Regents of the University of California

Division of Agriculture and Natural Resources

All rights reserved.

Produced by the Seed Biotechnology Center, UC Davis, in cooperation with the Biotechnology Workgroup of the UC Division of Agriculture and Natural Resources.

No part of this publication may be reproduced, stored in a retrieval system, or transmitted, in any form or by any means, electronic, mechanical, photocopying, recording, or otherwise, without the written permission of the publisher and the authors.

The University of California prohibits discrimination against or harassment of any person employed by or seeking employment with the University on the basis of race, color, national origin, religion, sex, physical or mental disability, medical condition (cancer-related or genetic characteristics), ancestry, marital status, age, sexual orientation, citizenship, or status as a covered veteran (special disabled veteran, Vietnam-era veteran or any other veteran who served on active duty during a war or in a campaign or expedition for which a campaign badge has been authorized). University Policy is intended to be consistent with the provisions of applicable State and Federal laws. Inquiries regarding the University's nondiscrimination policies may be directed to the Affirmative Action/Staff Personnel Services Director, University of California, Agriculture and Natural Resources, 300 Lakeside Drive, 6th floor, Oakland, CA 94612-3550; (510) 987-0096. For information about downloading this publication, telephone (530) 752-5112.

To simplify information, trade names of products have been used. No endorsement of named or illustrated products is intended, nor is criticism implied of similar products that are not mentioned or illustrated.

pr-12/02-GM/VFG

ISBN 978-1-60107-253-5

This publication has been anonymously peer reviewed for technical accuracy by University of California scientists and other qualified professionals. This review process was managed by the DANR Associate Editor for Farm Management and Economics. 